\title{
Şanlıurfa-Siverek'te Yaygın Toprak Gruplarının Besin Elementi Durumları ve Bunların Bazı Toprak Özellikleri ile İlişkileri
}

\author{
Mehmet YALÇIN $\$$ (D), Kerim Mesut ÇIMRİN (D) \\ Hatay Mustafa Kemal Üniversitesi, Ziraat Fakültesi, Toprak Bilimi ve Bitki Besleme Bölümü, Antakya-Hatay \\ 凶: myalcin@mku.edu.tr
}

\begin{abstract}
ÖZET
Çalışmada Şanlıurfa ili Siverek ilçesi yaygın toprak gurupları topraklarının bazı makro ve mikro besin elementlerinin içeriklerinin belirlenmesi ve toprağın bazı özelikleri ile ilişkilerinin saptanarak, verimlilik durumlarının değerlendirilmesi amaçlanmıştır.

$\mathrm{Bu}$ amaçla Siverek ilçesi yaygın toprak guruplarının topraklarını temsil edecek şekilde iki farklı derinlikten (0-20 ve $20-40 \mathrm{~cm}$ ) ve 38 ayrı noktadan olmak üzere toplamda 76 toprak örneği alınmıştır.

Araştırma sonuçlarına gore; toprakların \% azot içerikleri 0.01-0.25 ile alınabilir fosfor 0.32-29.98 ppm; değişebilir potasyum 390-3784 ppm; kalsiyum 12113-28515 ppm; magnezyum 734-8103 ppm arasinda belirlenmiştir. Ayrıca alınabilir bakır 0.54-3.61 ppm; demir 3.65-86.67 ppm; mangan 3.16-50.86 ppm ve çinko 0.09-4.22 ppm aralarında bulunmştur. Çalışma alanı topraklarının yarıdan fazlasında azot (\% 57.90), fosfor (\% 65.78) ve çinko (\% 63.16) içerikleri yönünden noksanlıklar belirlenirken, potasyum, kalsiyum, magnezyum, bakır, demir ve mangan içerikleri bakımından ise yeterli düzeyde olduğu belirlenmiştir.

Toprakların toplam azot ile tuz, silt, kireç ve organik madde; yarayışlı fosfor ile organik madde; değişebilir potasyum ile tuz, silt, organik madde ve KDK; kalsiyum ile $\mathrm{pH}$, tuz, silt ve KDK; magnezyum ve alınabilir demir ile kil; alınabilir demir ile tuz, silt, organik madde ve KDK; alınabilir mangan ile tuz, kil, silt ve organik madde ve alınabilir çinko ile organik madde arasında ise pozitif önemli ilişkiler belirlenmiştir. Toprakların toplam azot, değişebilir potasyum, kalsiyum, bakır, mangan ve çinko ile kum içerikleri; magnezyum, alınabilir bakır ve demir ile pH değerleri; kalsiyum ile kil içerikleri ve magnezyum ile kireç içerikleri arasında negatif önemli ilişkiler bulunmuştur.
\end{abstract}

Makale Tarihçesi
Geliş Tarihi: 30.07 .2018
Kabul Tarihi: 10.09 .2018
Anahtar Kelimeler
Şanlıurfa,
toprak özellikleri,
alınabilir besin elementi,
toprak analizleri

\section{Araştırma Makalesi}

\section{Nutrient Status and Their Relationships with Some Soil Properties of Widespread Soil Groups in Siverek, Şanlıurfa}

\section{ABSTRACT}

In the study, it was aimed to determine the contents of some macro and micro nutrients of the soil of the widespread Soil Groups of Siverek county, the relations with some properties of soil and the productivity conditions.

For this purpose, a total of 76 soil samples were taken from two different depths (0-20 and 20-40 cm) and 38 different locations to represent the widespread soil groups of the Siverek district.

According to the results of the research, the nitrogen contents of the soil was determined to be within $0.01-0.25$, available phosphorus 0.32 29.98 ppm; exchangeable potassium 390-3784 ppm; calcium 12113$28515 \mathrm{ppm}$; magnesium within 734-8103 ppm. It was also found that available copper was within 0.54-3.61 ppm; iron 3.65-86.67 ppm; manganese $3.16-50.86 \mathrm{ppm}$ and zinc $0.09-4.22 \mathrm{ppm}$. There were deficiencies in the content of nitrogen $(57.90 \%)$, phosphorus $(65.78 \%)$ and zinc $(63.16 \%)$ in more than half of the study site soils whereas no

\section{Article History}

Received : 30.07.2018

Accepted : 10.09.2018

\author{
Keywords \\ Şanlıurfa, \\ soil properties, \\ available plant nutrient, \\ soil analayses
}

\section{Research Article}


deficiencies in terms of potassium, calcium, magnesium, copper, iron and manganese content were found.

Positive significant relationships were determined between soils' total nitrogen, salt, silt, lime and organic matter; available phosphorus with organic matter; salt with changeable potassium, silt, organic matter and CEC; $\mathrm{pH}$ with calcium, salt, silt and CEC; magnesium and available iron with clay; available iron with salt, silt, organic matter and CEC; available manganese and salt, clay, silt and organic matter and available zinc and organic matter. Negative significant relationships were found among the soil's total nitrogen, variable potassium, calcium, copper, manganese and zinc and sand contents; between magnesium, soluble copper and iron and $\mathrm{pH}$ values; between calcium and clay contents, and magnesium and lime contents.

To cite: Yalçın M, Çimrin KM 2019. Şanlıurfa-Siverek’te Yaygın Toprak Gruplarının Besin Elementi Durumları ve Bunların Bazı Toprak Özellikleri ile İlişkileri. KSÜ Tar Doğa Derg 22(1) : 1-13, DOI : 10.18016/ksutarimdoga.v22i39650.412922

\section{GİŖ̧̇}

Birçok ülkenin kaynaklarının kullanılması dikkate alındığı zaman özellikle tarım sektöründe, toprak işleme açısından sürdürülebilir tarım alanlarının günümüzde tamamının değerlendirilmeye açıldığı ortaya çıkmaktadır. Sinırlı sayıda tarım yapılabilen toprakların özellikleri gözetilmeden, doğru olmayan toprak yönetimi ile erozyon, tuzlaşma, toprak kirliliği ve tarım arazilerinin tarım dışı faaliyetlerde kullanılması gibi olumsuzluklardan dolayı tarım dışına çıkarılması nedeniyle tarım yapılabilen toprakların alanları günden güne azalmaktadır. Tarımsal faaliyetlerdeki bu olumsuz koşullar düzeltilmediği taktirde sürekli artan nüfus Türkiye açısından önümüzdeki dönemler için beslenme problemlerinin ortaya çıkmasına neden olacaktır.

Toprak verimliliği sürdürülebilir tarımsal faaliyetler sonucu elde edilen ürün için en değerli koşulların başında gelir. Topraklardaki besin maddelerinin oransal olarak birinin diğerlerine göre az yada fazla olması, üretimi yapılan bitkiler için gerek bitkiye alınmaları gerekse bitkideki işlevlerine engel olabilmesi ve bitkilerin verim ve kaliteleri üzerinde olumsuz etkilere sebep olduğu bilinen bir gerçektir. Bunun yanı sıra, sürdürülebilir tarımda toprağın kimyasal ve fiziksel özelliklerin ortaya konularak, toprak içerisindeki besin maddeleri ile toprak özellikleri arsındaki ilişkinin bilinmesi, toprakta yapılacak olan gübrelemeden optimum düzeyde fayda sağlamak açısından oldukça önemlidir (Çimrin ve Boysan, 2006). Farklı yöre ve tarım alanlarının verimlilik durumlarının belirlenerek olası beslenme problemlerinin önceden belirlenmesi ve birçok ürünün verim ve sürekliliğini artırmak amacı ile birçok çalışma yürütülmüştür (Çetin ve Eraslan, 2015; Akça ve ark., 2015; Ateş ve Turan, 2015; Sönmez ve ark. 2014). Aynı yörede çalışan Saraçoğlu ve ark., (2014) yaptıkları çalışmada Şanlıurfa ili Halfeti ilçesi topraklarının bazı özellikleri ve bitki besin elementi kapsamlarının belirlenmesi amaçlanmıştır. Çalışma sonucunda, Halfeti ilçesi toprakları killi, kireçli, organik maddece yetersiz, bitkiye yarayışlı Fe içeriği bütün topraklarda yeter düzeyde bulunmuştur. Ayrıca toprakların $\mathrm{Zn}$ açısından \% 6.52 yüksek, $\mathrm{Mn}$ ve $\mathrm{Cu}$ bakımından yeterli, potasyum açısından ise tüm topraklarda önerilen düzeyin üzerinde olduğu bulunmuştur. Söylemez ve ark. (2017) Şanlıurfa yöresi zeytinliklerinin beslenme durumunu çalışmışlar ve çalışma sonucuna göre; toprakların genelde çok kireçli, hafif alkalin karekterli, tuzsuz ve organik madde miktarınca yetersiz olduğunu ifade etmişlerdir. Aynı zamanda yaprak ve toprak örneklerinde yapilan makro ve mikro besin element analiz sonuçlarına göre; bölgede bulunan zeytinliklerin genelinde besin element noksanlıkları ve bahçelerin neredeyse tamamında $\mathrm{P}, \mathrm{Zn}$ ve $\mathrm{B}$ içeriklerice yetersiz seviyelerde olduğu bildirilmiştir.

Çalışmada Şanlıurfa ili Siverek ilçesi yaygın toprak grupları topraklarının makro ve mikro besin elementi içeriklerinin belirlenerek, bunların bazı toprak özellikleri ile ilişkilerini ortaya koyarak, Siverek ilçesi yaygin toprak gruplarının (IUSS WRB Working Group, 2015) verimlilik durumlarının belirlenmesi amaçlanmıştır. Çalışmada Dünya'da yaygın olarak kullanılan Uluslararası Toprak Bilimleri Derneği Dünya Referans Tabanı Çalışma Grubu Toprak Grupları kullanılarak toprak özelliklerinin anlaşılabilirliği artırılmaya çalışılmıştır (IUSS WRB Working Group, 2015). Ayrıca yapılan çalışma, topraklarinın besin maddelerinin durumunun ortaya çıkarılması yanında bölgede yapılacak olan gübreleme faaliyetlerinin plan ve programlamasinin yapılmasında rehber olacaktır.

\section{MATERYAL ve YÖNTEM}

Çalışmada yöreyi temsil edecek şekilde Şanlıurfa ili Siverek bölgesi yaygın toprak guruplarına göre 38 ayrı nokta ve iki farklı $(0-20$ ve $20-40 \mathrm{~cm})$ derinlikten toplamda 76 toprak örneği usulüne uygun olarak alınmıştır (Şekil 1; Çizelge 1). 
Aynı gün laboratuvara getirilen toprak örnekleri gölgede hava kurusu olacak biçimde kurutulmuş ve 2 mm'lik elekten geçirilerek analize hazır hale getirilmiştir. Toprakların toplam çözünebilir tuz içerikleri saturasyon çamuru ekstraktında elektiriksel iletkenlik aletinde, $\mathrm{pH}$ değerleri ise $\mathrm{pH}$ metre aletinde ölçülmüştür (Richards, 1954). Topraklarda kireç $\left(\mathrm{CaCO}_{3}\right)$ içerikleri Scheibler kalsimetresi ile (Allison ve Moode, 1965), bünye hidrometre yöntemi ile (Bouyoucos, 1952), organik madde Jackson (1960) tarafindan bildirildiği şekilde modifiye edilmiş Walkley-Black yöntemiyle ve Katyon Değişim Kapasitesi (KDK) Chapman (1965)'a göre, toplam azot içerikleri Bremner (1965)'e; yarayışl fosfor Olsen ve ark., (1954), değişebilir potasyum, kalsiyum ve magnezyum Knudsen ve ark. (1982)'a göre belirlenirken, toprakların yarayışlı $\mathrm{Cu}, \mathrm{Fe}, \mathrm{Mn}$ ve $\mathrm{Zn}$ Lindsay ve Norvell (1978)'e göre belirlenmiştir. Toprak özellikleri ile besin elementleri arasındaki korelasyon ve regresyon analizleri SPSS 21.0 bilgisayar paket programında yapılmıştır (SPSS, 2012).
BULGULAR ve TARTIŞMA

Toprakların $\mathrm{pH}$, tuz, bünye, kireç, organik madde ve KDK analiz sonuçları:

Şanlıurfa ili Siverek ilçesi yaygın toprak gruplarını temsilen alınan toprakların bazı fiziksel ve kimyasal özelliklerine ait bulgular Çizelge 2'de verilmiştir. Araştırma topraklarının pH içeriği 6.91 ile 7.98 arasında değişerek ortalama olarak 7.55 olup, toprak örneklerinin pH'ları \% 42.10'u nötr ile \% 57.90'ı hafif alkalin reaksiyonlu olduğu görülmüştür. Şanlıurfa ili Halfeti ilçesi topraklarının bitki besin elementi kapsamlarının ve bazı özelliklerinin belirlendiği çalışmada, topraklarının pH'ları 7.38-7.83 arasında değişmekte olup ortalama 7.68 olarak bulunduğu ve toprak örneklerinin pH'larının nötr ile hafif alkalin arasında değiştiği bildirilmiştir (Saraçoğlu ve ark. 2014)

Şanlıurfa ili Siverek ilçesi topraklarının toplam tuz içerikleri \% 0.02-0.13 arasında değişirken ortalama olarak \% 0.07 olarak bulunmuş ve toprakların hepsinin tuzsuz sınıfa girdikleri belirlenmiştir.

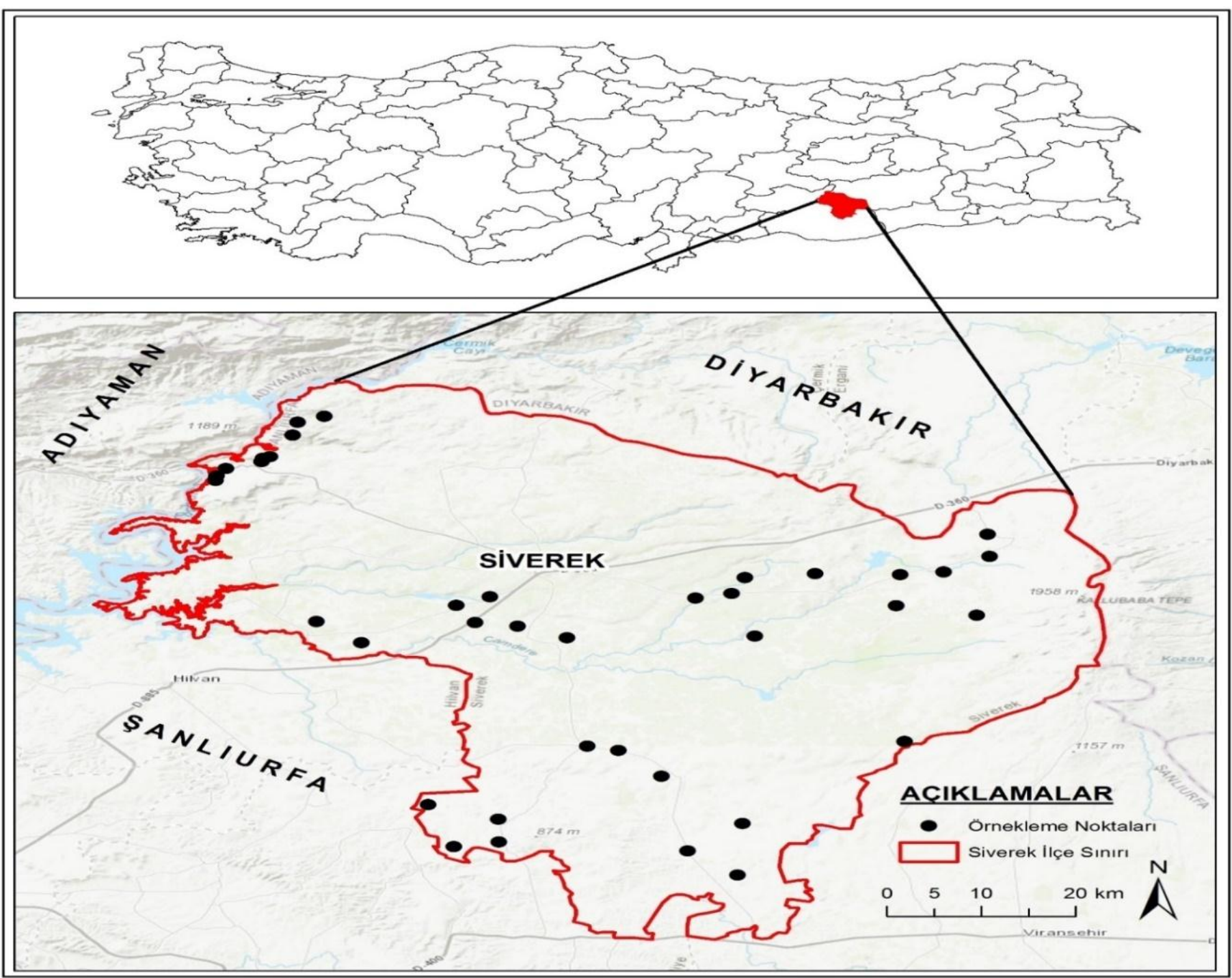

Şekil 1. Alınan toprak örneklerinin Siverek ilçe haritası üzerindeki gösterimi 
Çizelge 1. Toprak örneklerinin alındığı yerler

\begin{tabular}{|c|c|c|c|c|c|c|c|c|c|}
\hline $\begin{array}{l}\text { Toprak } \\
\text { No }\end{array}$ & Örnek Yeri & $\begin{array}{l}\text { Topral } \\
\text { WRB } \\
2015 \text { ) }\end{array}$ & $\begin{array}{lc}\mathrm{k} & \text { Sinifi } \\
\text { Working }\end{array}$ & $\begin{array}{l}\text { (IUSS } \\
\text { Group }\end{array}$ & $\begin{array}{l}\text { Toprak } \\
\text { No }\end{array}$ & Örnek Yeri & $\begin{array}{l}\text { Topra } \\
\text { WRB } \\
2015)\end{array}$ & $\begin{array}{c}\text { Sinifı } \\
\text { Working }\end{array}$ & $\begin{array}{l}\text { IUSS } \\
\text { Group }\end{array}$ \\
\hline 1 & Gözelek & & Cambiso & & 20 & Aşağıkarabahçe & & Vertisol & \\
\hline 2 & Karakoyun & & Cambiso & & 21 & Sabanlı-1 & & Cambisol & \\
\hline 3 & Çeltik & & Cambiso & & 22 & Karakeçi & & Cambisol & \\
\hline 4 & Çanakçı & & Cambiso & & 23 & Turna & & Cambisol & \\
\hline 5 & Yücelen-1 & & Cambiso & & 24 & Başbuk-1 & & Calcisol & \\
\hline 6 & Yücelen-2 & & Cambiso & & 25 & Başbuk-2 & & Calcisol & \\
\hline 7 & Ediz & & Cambiso & & 26 & Alayurt & & Cambisol & \\
\hline 8 & Çatlı & & Cambiso & & 27 & Aşağıkaracaören & & Cambisol & \\
\hline 9 & Erkonağ & & Cambiso & & 28 & Karadibek & & Cambisol & \\
\hline 10 & Gedik & & Cambiso & & 29 & Sabanlı-2 & & Vertisol & \\
\hline 11 & Gazi & & Cambiso & & 30 & Ergen-1 & & Cambisol & \\
\hline 12 & Eğriçay & & Cambiso & & 31 & Narlıkaya-1 & & Cambisol & \\
\hline 13 & Savucak & & Vertisol & & 32 & Narlıkaya-2 & & Cambisol & \\
\hline 14 & Karacadağ-1 & & Vertisol & & 33 & Narlıkaya-3 & & Cambisol & \\
\hline 15 & Sumaklı & & Vertisol & & 34 & Ergen-2 & & Cambisol & \\
\hline 16 & Keçikıran & & Cambiso & & 35 & Ergen-3 & & Cambisol & \\
\hline 17 & Karacadağ-2 & & Cambiso & & 36 & Kayalı-1 & & Cambisol & \\
\hline 18 & Altınahır & & Cambiso & & 37 & Kayalı-2 & & Cambisol & \\
\hline 19 & Altınlı & & Cambiso & & 38 & Kayalı-3 & & Cambisol & \\
\hline
\end{tabular}

Çizelge 2. Şanlıurfa ili Siverek ilçesi yaygın toprak guruplarının bazı fiziksel ve kimyasal özellikleri

\begin{tabular}{|c|c|c|c|c|c|c|c|c|c|c|}
\hline $\begin{array}{l}\text { Toprak } \\
\text { No }\end{array}$ & Derinlik & $\mathrm{pH}$ & $\begin{array}{l}\text { Tuz } \\
\%\end{array}$ & $\begin{array}{l}\text { Kil } \\
\%\end{array}$ & $\begin{array}{l}\text { Kum } \\
\%\end{array}$ & $\begin{array}{l}\text { Silt } \\
\%\end{array}$ & $\begin{array}{l}\text { Testür } \\
\text { Sinıfi }\end{array}$ & $\begin{array}{l}\text { Kireç } \\
\%\end{array}$ & $\begin{array}{l}\text { O.M. } \\
\%\end{array}$ & $\begin{array}{l}\mathrm{KDK} \\
\mathrm{me} / 100 \mathrm{~g}\end{array}$ \\
\hline \multirow[t]{2}{*}{1} & $0-20$ & 7.28 & 0.04 & 24.32 & 21.68 & 54.00 & $\mathrm{SiL}$ & 1.47 & 1.90 & 52.14 \\
\hline & $20-40$ & 7.29 & 0.05 & 26.32 & 23.68 & 50.00 & $\mathrm{SiL}$ & 1.47 & 1.88 & 51.34 \\
\hline \multirow[t]{2}{*}{2} & $0-20$ & 7.67 & 0.08 & 35.04 & 9.68 & 55.28 & $\mathrm{SiCL}$ & 2.71 & 1.95 & 67.09 \\
\hline & $20-40$ & 7.74 & 0.08 & 31.76 & 15.68 & 52.56 & $\mathrm{SiCL}$ & 2.69 & 1.66 & 59.45 \\
\hline \multirow[t]{2}{*}{3} & $0-20$ & 7.74 & 0.06 & 30.32 & 13.68 & 56.00 & SiCL & 1.31 & 1.53 & 58.23 \\
\hline & $20-40$ & 7.79 & 0.07 & 30.32 & 14.96 & 54.72 & $\mathrm{SiCL}$ & 1.54 & 1.55 & 57.25 \\
\hline \multirow[t]{2}{*}{4} & $0-20$ & 7.39 & 0.10 & 32.32 & 11.68 & 56.00 & $\mathrm{SiCL}$ & 1.31 & 2.11 & 66.56 \\
\hline & $20-40$ & 7.42 & 0.10 & 32.32 & 14.96 & 52.72 & $\mathrm{SiCL}$ & 1.69 & 1.99 & 60.89 \\
\hline \multirow[t]{2}{*}{5} & $0-20$ & 7.44 & 0.10 & 34.32 & 7.68 & 58.00 & $\mathrm{SiCL}$ & 1.46 & 1.90 & 67.29 \\
\hline & $20-40$ & 7.40 & 0.10 & 32.32 & 10.96 & 56.72 & $\mathrm{SiCL}$ & 1.46 & 1.66 & 66.01 \\
\hline \multirow[t]{2}{*}{6} & $0-20$ & 7.65 & 0.08 & 27.04 & 19.68 & 53.28 & $\mathrm{SiCL}$ & 3.16 & 2.27 & 57.63 \\
\hline & $20-40$ & 7.58 & 0.10 & 30.32 & 17.68 & 52.00 & $\mathrm{SiCL}$ & 1.54 & 2.05 & 55.93 \\
\hline \multirow[t]{2}{*}{7} & $0-20$ & 7.74 & 0.08 & 30.32 & 13.68 & 56.00 & $\mathrm{SiCL}$ & 1.54 & 1.85 & 56.34 \\
\hline & $20-40$ & 7.80 & 0.08 & 31.04 & 20.40 & 48.56 & $\mathrm{CL}$ & 1.92 & 1.49 & 55.51 \\
\hline \multirow[t]{2}{*}{8} & $0-20$ & 7.57 & 0.08 & 32.32 & 22.96 & 44.72 & $\mathrm{CL}$ & 4.39 & 3.33 & 53.47 \\
\hline & $20-40$ & 7.55 & 0.08 & 32.32 & 12.40 & 55.28 & $\mathrm{SiCL}$ & 2.69 & 3.26 & 60.58 \\
\hline \multirow[t]{2}{*}{9} & $0-20$ & 7.88 & 0.05 & 26.32 & 20.40 & 53.28 & SiL & 10.47 & 1.64 & 59.09 \\
\hline & $20-40$ & 7.85 & 0.05 & 30.32 & 22.96 & 46.72 & CL & 10.16 & 1.60 & 59.16 \\
\hline \multirow[t]{2}{*}{10} & $0-20$ & 7.48 & 0.09 & 34.32 & 12.40 & 53.28 & $\mathrm{SiCL}$ & 0.38 & 1.80 & 62.18 \\
\hline & $20-40$ & 7.52 & 0.10 & 32.32 & 12.96 & 54.72 & $\mathrm{SiCL}$ & 1.46 & 1.55 & 61.15 \\
\hline \multirow[t]{2}{*}{11} & $0-20$ & 7.41 & 0.07 & 36.32 & 8.40 & 55.28 & $\mathrm{SiCL}$ & 1.15 & 1.58 & 68.11 \\
\hline & $20-40$ & 7.48 & 0.07 & 40.32 & 8.96 & 50.72 & $\mathrm{SiC}$ & 1.31 & 1.38 & 74.83 \\
\hline \multirow[t]{2}{*}{12} & $0-20$ & 7.36 & 0.06 & 30.32 & 12.40 & 57.28 & $\mathrm{SiCL}$ & 1.15 & 2.51 & 64.69 \\
\hline & $20-40$ & 7.41 & 0.07 & 34.32 & 12.96 & 52.72 & $\mathrm{SiCL}$ & 1.15 & 2.41 & 63.47 \\
\hline \multirow[t]{2}{*}{13} & $0-20$ & 7.11 & 0.06 & 67.76 & 2.40 & 29.84 & $\mathrm{C}$ & 1.08 & 1.85 & 61.18 \\
\hline & $20-40$ & 7.07 & 0.06 & 46.32 & 8.96 & 44.72 & $\mathrm{SiC}$ & 1.31 & 1.83 & 62.35 \\
\hline \multirow[t]{2}{*}{14} & $0-20$ & 7.06 & 0.06 & 65.76 & 8.40 & 25.84 & $\mathrm{C}$ & 1.15 & 2.17 & 62.75 \\
\hline & $20-40$ & 7.10 & 0.06 & 64.32 & 11.68 & 24.00 & $\mathrm{C}$ & 1.23 & 1.88 & 61.13 \\
\hline \multirow[t]{2}{*}{15} & $0-20$ & 7.27 & 0.07 & 52.32 & 14.40 & 33.28 & $\mathrm{C}$ & 1.00 & 1.58 & 63.80 \\
\hline & $20-40$ & 7.36 & 0.07 & 42.32 & 14.40 & 43.28 & $\mathrm{SiC}$ & 1.39 & 1.49 & 74.03 \\
\hline \multirow[t]{2}{*}{16} & $0-20$ & 7.67 & 0.08 & 30.32 & 12.40 & 57.28 & SiCL & 3.52 & 1.27 & 63.86 \\
\hline & $20-40$ & 7.73 & 0.08 & 32.32 & 15.68 & 52.00 & $\mathrm{SiCL}$ & 4.52 & 1.11 & 60.29 \\
\hline
\end{tabular}


Çizelge 2. (Devam)

\begin{tabular}{|c|c|c|c|c|c|c|c|c|c|c|}
\hline $\begin{array}{l}\text { Toprak } \\
\text { No }\end{array}$ & Derinlik & $\mathrm{pH}$ & $\begin{array}{l}\text { Tuz } \\
\%\end{array}$ & $\begin{array}{l}\text { Kil } \\
\%\end{array}$ & $\begin{array}{l}\text { Kum } \\
\%\end{array}$ & $\begin{array}{l}\text { Silt } \\
\%\end{array}$ & $\begin{array}{l}\text { Testür } \\
\text { Sinifi }\end{array}$ & $\begin{array}{l}\text { Kireç } \\
\%\end{array}$ & $\begin{array}{l}\text { O.M. } \\
\%\end{array}$ & $\begin{array}{l}\text { KDK } \\
\mathrm{me} / 100 \mathrm{~g}\end{array}$ \\
\hline \multirow[t]{2}{*}{17} & $0-20$ & 7.73 & 0.07 & 30.32 & 16.40 & 53.28 & $\mathrm{SiCL}$ & 2.37 & 1.98 & 46.09 \\
\hline & $20-40$ & 7.75 & 0.07 & 26.32 & 21.68 & 52.00 & SiL & 2.68 & 1.69 & 53.91 \\
\hline \multirow[t]{2}{*}{$\overline{18}$} & $0-20$ & 7.78 & 0.06 & 34.32 & 8.40 & 57.28 & $\mathrm{SiCL}$ & 3.16 & 1.98 & 59.69 \\
\hline & $20-40$ & 7.82 & 0.07 & 28.32 & 13.68 & 58.00 & $\mathrm{SiCL}$ & 3.69 & 1.88 & 64.63 \\
\hline \multirow[t]{2}{*}{19} & $0-20$ & 7.75 & 0.07 & 31.04 & 14.40 & 54.56 & $\mathrm{SiCL}$ & 1.46 & 1.53 & 59.26 \\
\hline & $20-40$ & 7.71 & 0.07 & 30.32 & 17.68 & 52.00 & $\mathrm{SiCL}$ & 1.77 & 2.10 & 51.35 \\
\hline \multirow[t]{2}{*}{$\overline{20}$} & $0-20$ & 6.98 & 0.04 & 48.32 & 18.40 & 33.28 & C & 8.74 & 2.17 & 40.28 \\
\hline & $20-40$ & 6.91 & 0.04 & 44.32 & 15.68 & 40.00 & C & 9.39 & 2.16 & 40.93 \\
\hline \multirow[t]{2}{*}{21} & $0-20$ & 7.82 & 0.06 & 30.32 & 16.40 & 53.28 & SiCL & 6.23 & 2.01 & 57.66 \\
\hline & $20-40$ & 7.85 & 0.06 & 30.32 & 15.68 & 54.00 & $\mathrm{SiCL}$ & 6.16 & 1.74 & 51.76 \\
\hline \multirow[t]{2}{*}{22} & $0-20$ & 7.37 & 0.09 & 24.32 & 22.40 & 53.28 & SiL & 4.23 & 2.48 & 55.95 \\
\hline & $20-40$ & 7.39 & 0.08 & 30.32 & 19.68 & 50.00 & $\mathrm{SiCL}$ & 4.62 & 2.43 & 50.21 \\
\hline \multirow[t]{2}{*}{23} & $0-20$ & 7.51 & 0.10 & 28.32 & 16.40 & 55.28 & SiCL & 2.31 & 2.01 & 61.35 \\
\hline & $20-40$ & 7.54 & 0.12 & 32.32 & 13.68 & 54.00 & $\mathrm{SiCL}$ & 1.62 & 2.02 & 55.95 \\
\hline \multirow[t]{2}{*}{24} & $0-20$ & 7.65 & 0.08 & 30.32 & 14.40 & 55.28 & SiCL & 13.86 & 2.43 & 54.21 \\
\hline & $20-40$ & 7.71 & 0.08 & 28.32 & 14.96 & 56.72 & $\mathrm{SiCL}$ & 14.55 & 2.38 & 49.57 \\
\hline \multirow[t]{2}{*}{25} & $0-20$ & 7.76 & 0.04 & 36.32 & 12.96 & 50.72 & SiCL & 7.77 & 2.56 & 50.37 \\
\hline & $20-40$ & 7.79 & 0.04 & 36.32 & 13.68 & 50.00 & $\mathrm{SiCL}$ & 8.47 & 2.35 & 49.31 \\
\hline \multirow[t]{2}{*}{26} & $0-20$ & 7.81 & 0.05 & 28.32 & 2.96 & 68.72 & $\mathrm{SiCL}$ & 1.92 & 1.74 & 63.99 \\
\hline & $20-40$ & 7.88 & 0.04 & 23.60 & 10.96 & 65.44 & SiL & 2.69 & 1.77 & 47.78 \\
\hline \multirow[t]{2}{*}{27} & $0-20$ & 7.77 & 0.06 & 28.32 & 13.68 & 58.00 & SiCL & 2.31 & 1.93 & 53.22 \\
\hline & $20-40$ & 7.74 & 0.06 & 30.32 & 14.96 & 54.72 & $\mathrm{SiCL}$ & 2.69 & 1.94 & 46.83 \\
\hline \multirow[t]{2}{*}{28} & $0-20$ & 7.76 & 0.05 & 30.32 & 17.68 & 52.00 & SiCL & 8.31 & 2.38 & 47.73 \\
\hline & $20-40$ & 7.82 & 0.06 & 28.32 & 22.96 & 48.72 & SiCL & 8.39 & 2.43 & 44.67 \\
\hline \multirow[t]{2}{*}{29} & $0-20$ & 7.49 & 0.12 & 46.32 & 21.68 & 32.00 & $\mathrm{C}$ & 3.46 & 3.35 & 50.64 \\
\hline & $20-40$ & 7.57 & 0.13 & 50.32 & 14.96 & 34.72 & C & 4.16 & 3.15 & 49.21 \\
\hline \multirow[t]{2}{*}{30} & $0-20$ & 7.30 & 0.05 & 26.32 & 11.68 & 62.00 & SiL & 1.08 & 2.54 & 53.11 \\
\hline & $20-40$ & 7.39 & 0.05 & 27.76 & 30.96 & 41.28 & SiCL & 1.54 & 2.21 & 52.62 \\
\hline \multirow[t]{2}{*}{31} & $0-20$ & 7.06 & 0.02 & 34.32 & 55.68 & 10.00 & SCL & 1.15 & 1.56 & 46.62 \\
\hline & $20-40$ & 7.09 & 0.02 & 34.32 & 54.24 & 11.44 & SCL & 0.85 & 1.44 & 42.79 \\
\hline \multirow{2}{*}{32} & $0-20$ & 7.22 & 0.02 & 37.04 & 47.68 & 15.28 & $\mathrm{SC}$ & 1.15 & 1.37 & 45.65 \\
\hline & $20-40$ & 7.31 & 0.02 & 37.04 & 48.24 & 14.72 & $\mathrm{SC}$ & 1.62 & 1.16 & 41.90 \\
\hline \multirow[t]{2}{*}{33} & $0-20$ & 7.94 & 0.03 & 26.32 & 31.68 & 42.00 & $\mathrm{~L}$ & 8.47 & 1.53 & 57.61 \\
\hline & $20-40$ & 7.98 & 0.03 & 28.32 & 42.24 & 29.44 & $\mathrm{CL}$ & 8.47 & 1.58 & 42.19 \\
\hline \multirow[t]{2}{*}{34} & $0-20$ & 7.97 & 0.04 & 32.32 & 42.96 & 24.72 & $\mathrm{CL}$ & 7.54 & 1.43 & 43.37 \\
\hline & $20-40$ & 7.95 & 0.04 & 26.32 & 44.96 & 28.72 & $\mathrm{~L}$ & 8.01 & 1.27 & 39.10 \\
\hline \multirow[t]{2}{*}{35} & $0-20$ & 7.78 & 0.04 & 37.76 & 37.68 & 24.56 & $\mathrm{CL}$ & 11.55 & 2.98 & 56.23 \\
\hline & $20-40$ & 7.86 & 0.04 & 36.32 & 36.24 & 27.44 & $\mathrm{CL}$ & 12.55 & 3.10 & 40.60 \\
\hline 36 & $0-20$ & 7.32 & 0.02 & 38.32 & 45.68 & 16.00 & $\mathrm{CL}$ & 1.00 & 1.21 & 41.07 \\
\hline & $20-40$ & 7.41 & 0.02 & 32.32 & 54.96 & 12.72 & SCL & 1.31 & 1.13 & 34.04 \\
\hline 37 & $0-20$ & 7.47 & 0.02 & 30.32 & 62.24 & 7.44 & SCL & 1.54 & 1.48 & 42.73 \\
\hline & $20-40$ & 7.52 & 0.02 & 28.32 & 62.96 & 8.72 & SCL & 1.54 & 1.38 & 36.74 \\
\hline 38 & $0-20$ & 7.43 & 0.03 & 36.32 & 57.68 & 6.00 & $\mathrm{SC}$ & 1.54 & 1.74 & 43.99 \\
\hline & $20-40$ & 7.46 & 0.03 & 40.32 & 52.24 & 7.44 & $\mathrm{SC}$ & 1.54 & 1.60 & 39.25 \\
\hline Min & & 6.91 & 0.02 & 24.32 & 2.40 & 6.00 & & 0.38 & 1.11 & 34.04 \\
\hline $\operatorname{Max}$ & & 7.98 & 0.13 & 67.76 & 62.96 & 68.72 & & 14.55 & 3.35 & 74.83 \\
\hline Ort.(Av.) & $0-20$ & 7.54 & 0.06 & 34.61 & 21.08 & 44.31 & & 3.64 & 1.99 & 55.66 \\
\hline Ort.(Av.) & $20-40$ & 7.57 & 0.07 & 33.68 & 23.07 & 43.25 & & 3.84 & 1.89 & 52.86 \\
\hline & Ort.(Av.) & 7.55 & 0.07 & 34.15 & 22.08 & 43.78 & & 3.74 & 1.94 & 54.26 \\
\hline
\end{tabular}

Şanlıurfa ili ve çevresinde daha önceden yapılmış olan birçok çalışmada, Harran ile Akçakale'nin bir kısmı hariç, toprakların tuzluluk yönünden herhangi bir sorunun olmadığı bildirilmektedir (Kızılgöz ve ark. (1999), Seyrek ve ark. (1999) ve Saraçoğlu ve ark. (2009; 2010; 2013, 2014).
Siverek ilçesi topraklarının sırasıyla kil, kum ve silt miktarları ortalama olarak \% $34.15,22.08$ ve 43.78 bulunmuştur. Araştırma topraklarının kireç içerikleri $\%$ 0.38-14.55 arasında değişirken ortalama \% 3.74 olarak genellikle kireçli ile orta kireçli olarak belirlenmiştir. Topraklarının organik madde içeriği \% 1.11-3.35 olarak belirlenirken ortalama organik 
madde \% 1.94 bulunmuştur. Topraklarda katyon değişim kapasitesi (KDK) incelendiğinde; toprak örneklerinin 34.04-74.83 me/100 g olarak bulunmuş olup ortalama KDK içeriği ise 54.26 me/100 g olarak belirlenmiştir (Çizelge 2).

Aynı bölgede Söylemez ve ark. (2017) Şanlıurfa yöresi zeytinliklerinin beslenme durumunu çalışmışlar ve çalışma sonucuna göre; toprakların genel olarak çok kireçli, hafif alkalin yapıda, tuzsuz ve organik madde miktarının yetersiz olduğunu bildirmişlerdir.

Toprak Örneklerinin Bazı Bitki Besin Elementi Düzeyleri

Azot

Şanlıurfa ili Siverek ilçesi yaygın toprak guruplarını temsilen alınan araştırma alanı topraklarının toplam azot (N), yarayışlı fosfor (P), değişebilir $\mathrm{K}, \mathrm{Ca}, \mathrm{Mg}$ ile alınabilir $\mathrm{Cu}, \mathrm{Fe}, \mathrm{Mn}$ ve $\mathrm{Zn}$ içerikleri Çizelge 3'de verilmiştir. Araştırma topraklarının toplam azot içerikleri en düşük \% 0.01 iken en yüksek azot içeriği $\% 0.25$ olarak belirlenmiştir. Toprakların 0-20 cm derinliğindeki örneklerinin ortalama azot içeriği \% 0.10 iken $20-40 \mathrm{~cm}$ derinlikteki örneklerde ise \% 0.10 olup iki derinlikte ortalama olarak \% 0.10 bulunmuştur. Toprak örneklerinin toplam azot içerikleri Kovancı (1969)'nın verdiği sınıflandırmaya göre toprakların \% 17.11'i azotça çok düşük $(<0.05)$, \% 40.79 'u düşük (0.05-0.09), \% 26.31'i orta (0.09-0.17) ve \% 15.79'u ise yüksek (0.17-0.32) olduğu görülmüştür (Çizelge 3). Karaduman ve Çimrin (2016) Gaziantep yöresi tarım topraklarının besin elementi durumları ve bunların bazı toprak özellikleri ile ilişkilerini araştırdıkları komşu ildeki bir çalışmada, toprakların toplam azot içerikleri bakımından \% 0.96'sının çok fazla (> \% 0.320), \% 11.32' sinin fazla (\% 0.170-0.320), $\%$ 32.07'sinin yeterli (\% 0.090-0.170), \% 33.01'inin düşük (\% 0.045-0.090) ve \% 22.64' ünün çok düşük (< $\% 0.045$ ) olduğunu belirliyerek benzer sonuçlar ortaya koymuşlardır.

\section{Fosfor}

Siverek ilçesi yaygın toprak gurupları topraklarının alınabilir fosfor içerikleri en düşük $0.32 \mathrm{ppm}$ iken en yüksek 29.98 ppm olarak belirlenmiştir. Toprakların 0-20 cm derinliğindeki ortalama fosfor içeriği $7.86 \mathrm{ppm}$ iken $20-40 \mathrm{~cm}$ derinlikteki örneklerde ortalama ise $7.69 \mathrm{ppm}$ olup, bütün örneklerin ortalaması $7.78 \mathrm{ppm}$ olarak bulunmuştur. Siverek ilçesi yaygin toprak gurupları toprakları FAO (1990)'nun bildirdiği sınır değerlerine göre \% 10.52' sinin fosfor içeriği çok düşük $(<2.5 \mathrm{ppm}), \% 55.26$ ' sinın düşük $(2.5-8.0 \mathrm{ppm}), \%$ 31.58 ' i yeterli $(8-25 \mathrm{ppm})$ ve \% 2.64' ü ise fazla (25-80 ppm) düzeyde olduğu bulunmuştur (Çizelge 3). Bu sonuçlara göre toprakların çok büyük bir kısmında fosforlu gübreleme yapılması önerilebilir. Genelde Türkiye topraklarının farklı bölgelerinde yapılan birçok çalışmada yaygın fosfor noksanlığı görülmektedir (Çimrin ve Boysan, (2006); Akça ve ark. (2015); Karaduman ve Çimrin (2016); Yalçın ve Çimrin (2017); Söylemez ve ark. (2017)).

\section{Potasyum}

Araştırma topraklarının değişebilir potasyum içeriğ en düşük 390 ppm iken en yüksek 3784 ppm olarak belirlenmiştir. Toprakların 0-20 $\mathrm{cm}$ derinliğindeki örneklerinin ortalama değişebilir potasyum içeriği $1746 \mathrm{ppm}$ iken $20-40 \mathrm{~cm}$ derinliklerde ise $1651 \mathrm{ppm}$ olup her iki derinlikte ortalama 1698 ppm olarak bulunmuştur. Toprak örneklerinin değişebilir potasyum içerikleri Sumner ve Miller (1996)'in verdiği sınır değerlere göre, sinıflandırıldığında, \% 19.74'ü yüksek (370-1000 ppm) ve \% 80.26'sının çok yüksek (>1000 ppm) düzeyde olduğu belirlenmiştir (Çizelge 3). Aynı bölgede yapılan çalışmalarda; Söylemez ve ark. (2017) Şanliurfa yöresi zeytinliklerinin beslenme durumunun belirlenmesiiçin yaptıkları çalışmada değişebilir potasyum içeriklerini $228 \mathrm{ppm}$ ile $678 \mathrm{ppm}$ arasında ve Saraçoğlu ve ark. (2014) Şanlıurfa ili Halfeti ilçesi topraklarının bazı özellikleri ve bitki besin elementi kapsamlarının belirlenmesi amacıyla yaptıkları çalışmada ise değişebilir potasyum içeriklerini 54-316 $\mathrm{kg} \mathrm{K}_{2} \mathrm{O} \mathrm{da}^{-1}$ arasında sonuçlar elde etmişlerdir.

\section{Kalsiyum}

Toprakların kalsiyum içeriği örneklerde en düşük 12113 ppm iken en yüksek kalsiyum içeriği 28515 ppm olarak belirlenmiştir. Toprakların 0-20 cm derinliğindeki örneklerinin ortalama kalsiyum içeriği 21863 ppm iken 20-40 cm derinlikteki örneklerde ise 21592 ppm olup iki derinlikte ortalama olarak 21727 ppm bulunmuştur. Toprak örneklerinin yarayışlı kalsiyum içerikleri Sumner ve Miller (1996)'in verdiği sınır değerlere göre toprakların tümünde kalsiyum içeriğinin çok fazla (>10000 ppm) seviyede olduğu belirlenmiştir (Çizelge 3). Genelde hafif alkalin reaksiyon veren bu toprakların büyük bir kısmında yarayışlı kalsiyum açısından fazlalık gözlenmektedir. Aynı bölgede yapılan çalışmada Söylemez ve ark. (2017) Şanliurfa yöresi zeytinliklerinin beslenme durumunun belirlenmesi amaciyla yaptıkları çalışmada toprakları kalsiyum içeriklerini 1242-8516 ppm arasında belirleyerek bu toprakların yüksek oranda kalsiyum içeriğini bildirmişlerdir.

\section{Magnezyum}

Toprakların magnezyum içeriği örneklerde en düşük 734 ppm iken en yüksek kalsiyum içeriği 8103 ppm olarak belirlenmiştir. Toprakların 0-20 cm derinliğindeki örneklerinin ortalama kalsiyum içeriği 2786 ppm iken 20-40 cm derinlikteki örneklerde ise 2806 ppm olup iki derinlikte ortalama olarak 2796 ppm bulunmuştur. Toprak örneklerinin magnezyum içeriği Sumner ve Miller (1996)'a göre 
sınıflandırılmıştır ve toprakların magnezyum içeriği \% 22.37 'si fazla (480-1500 ppm) ve \% 77.63'ü ise çok fazla $(>1500$ ppm $)$ seviyede magnezyum içerdiği belirlenmiştir (Çizelge 3). Farklı bölgelerde yapılan; Gürel ve Başar (2006) Yalova yöresi seralarında yetiştirilen, hıyarın beslenme durumlarının belirlenmesi amacıyla yaptıkları çalışmada toprakların magnezyum içeriklerini 434 ppm ile 1282 ppm arasında belirlemişlerdir. Demir ve Erdal (2016) Antalya ili Merkez, Kumluca, Serik ve Gazipaşa ilçelerinde serada üretilen domates bitkisinin bor durumlarının değerlendirilmesi amacıyla yaptıkları çalışma sonucunda magnezyum içeriğini $95 \mathrm{ppm}$ ile 1055 ppm değerleri arasında belirlemişlerdir.

\section{Bakır}

Toprakların bakır içeriği örneklerde en düşük 0.54 ppm iken en yüksek bakır içeriği 3.61 ppm olarak belirlenmiştir. Toprakların $0-20 \mathrm{~cm}$ derinliğindeki örneklerinin ortalama bakır içeriği 1.68 ppm iken 20$40 \mathrm{~cm}$ derinlikteki örneklerde ise $1.72 \mathrm{ppm}$ olup iki derinlikte ortalama olarak 1.70 ppm bulunmuştur. Toprak örneklerinin bakır içeriği Linsay ve Norvell (1978) bildirdiği sınır değerler ele alındığında toprakların bütününün alınabilir bakır içeriği bakımından yeterli düzeyde $(>0.2 \quad \mathrm{ppm})$ olduğu görülmüştür (Çizelge 3). Şanlıurfa, Halfeti ilçesi topraklarında çalışan Saraçoğlu ve ark. (2014) toprak örneklerinin $\mathrm{Cu}$ kapsamlarını benzer olarak 1.61-7.68 ppm arasında, ortalama 3.33 ppm olarak bulduklarını bildirmişlerdir.

\section{Demir}

Çalışma alanının topraklarının alınabilir demir içerikleri örneklerde en düşük 3.65 ppm iken en yüksek demir içeriği $86.67 \mathrm{ppm}$ olarak belirlenmiştir. Toprakların $\quad 0-20 \quad \mathrm{~cm}$ derinliğindeki örneklerinin ortalaması demir içeriği $16.84 \mathrm{ppm}$ iken $20-40 \mathrm{~cm}$ derinlikteki örneklerde ise $16.25 \mathrm{ppm}$ olup her iki derinliğin ortalaması olarak $16.55 \mathrm{ppm}$ olarak bulunmuştur.

Çizelge 3. Şanlıurfa ili Siverek ilçesi yaygın toprak guruplarının N, P, K, Ca, Mg, Cu, Fe, Mn, Zn içerikleri

\begin{tabular}{|c|c|c|c|c|c|c|c|c|c|c|}
\hline Toprak No & Derinlik & $\begin{array}{l}\mathrm{N} \\
\%\end{array}$ & $\begin{array}{l}\mathrm{P} \\
\mathrm{ppm}\end{array}$ & $\begin{array}{l}\mathrm{K} \\
\mathrm{ppm}\end{array}$ & $\begin{array}{l}\mathrm{Ca} \\
\mathrm{ppm}\end{array}$ & $\begin{array}{l}\mathrm{Mg} \\
\mathrm{ppm}\end{array}$ & $\begin{array}{l}\mathrm{Cu} \\
\mathrm{ppm}\end{array}$ & $\begin{array}{l}\mathrm{Fe} \\
\mathrm{ppm}\end{array}$ & $\begin{array}{l}\mathrm{Mn} \\
\mathrm{ppm}\end{array}$ & $\begin{array}{l}\mathrm{Zn} \\
\mathrm{ppm}\end{array}$ \\
\hline 1 & $\begin{array}{l}0-20 \\
20-40\end{array}$ & $\begin{array}{l}0.09 \\
0.12\end{array}$ & $\begin{array}{l}2.30 \\
3.40\end{array}$ & $\begin{array}{l}1074 \\
1092\end{array}$ & $\begin{array}{l}17781 \\
17678\end{array}$ & $\begin{array}{l}3221 \\
3285\end{array}$ & $\begin{array}{l}1.69 \\
1.88\end{array}$ & $\begin{array}{l}21.50 \\
16.12\end{array}$ & $\begin{array}{l}17.75 \\
15.62\end{array}$ & $\begin{array}{l}1.39 \\
0.51\end{array}$ \\
\hline 2 & $\begin{array}{l}0-20 \\
20-40\end{array}$ & $\begin{array}{l}0.06 \\
0.08\end{array}$ & $\begin{array}{l}4.62 \\
3.71\end{array}$ & $\begin{array}{l}1847 \\
1821\end{array}$ & $\begin{array}{l}27308 \\
26553\end{array}$ & $\begin{array}{l}1893 \\
1900\end{array}$ & $\begin{array}{l}1.62 \\
1.78\end{array}$ & $\begin{array}{l}12.14 \\
13.23\end{array}$ & $\begin{array}{l}14.26 \\
16.00\end{array}$ & $\begin{array}{l}0.55 \\
0.46\end{array}$ \\
\hline 3 & $\begin{array}{l}0-20 \\
20-40 \\
\end{array}$ & $\begin{array}{l}0.05 \\
0.08 \\
\end{array}$ & $\begin{array}{l}4.43 \\
3.59 \\
\end{array}$ & $\begin{array}{l}1726 \\
1718 \\
\end{array}$ & $\begin{array}{l}22596 \\
23029 \\
\end{array}$ & $\begin{array}{l}2216 \\
2277 \\
\end{array}$ & $\begin{array}{l}1.29 \\
1.36 \\
\end{array}$ & $\begin{array}{l}10.09 \\
10.08 \\
\end{array}$ & $\begin{array}{l}18.33 \\
19.73 \\
\end{array}$ & $\begin{array}{l}0.39 \\
0.40 \\
\end{array}$ \\
\hline 4 & $\begin{array}{l}0-20 \\
20-40\end{array}$ & $\begin{array}{l}0.13 \\
0.15 \\
\end{array}$ & $\begin{array}{l}5.97 \\
8.30\end{array}$ & $\begin{array}{l}1720 \\
1735\end{array}$ & $\begin{array}{l}20587 \\
20440 \\
\end{array}$ & $\begin{array}{l}4619 \\
4623\end{array}$ & $\begin{array}{l}3.50 \\
3.44\end{array}$ & $\begin{array}{l}43.15 \\
42.43\end{array}$ & $\begin{array}{l}16.27 \\
12.86\end{array}$ & $\begin{array}{l}1.99 \\
1.95\end{array}$ \\
\hline 5 & $\begin{array}{l}0-20 \\
20-40\end{array}$ & $\begin{array}{l}0.06 \\
0.06 \\
\end{array}$ & $\begin{array}{l}7.18 \\
7.70 \\
\end{array}$ & $\begin{array}{l}2176 \\
1920 \\
\end{array}$ & $\begin{array}{l}22645 \\
22904 \\
\end{array}$ & $\begin{array}{l}3999 \\
3908 \\
\end{array}$ & $\begin{array}{l}1.40 \\
1.40 \\
\end{array}$ & $\begin{array}{l}12.54 \\
11.41 \\
\end{array}$ & $\begin{array}{l}32.63 \\
24.71 \\
\end{array}$ & $\begin{array}{l}0.40 \\
0.46 \\
\end{array}$ \\
\hline 6 & $\begin{array}{l}0-20 \\
20-40 \\
\end{array}$ & $\begin{array}{l}0.09 \\
0.10 \\
\end{array}$ & $\begin{array}{l}7.70 \\
3.99 \\
\end{array}$ & $\begin{array}{l}1658 \\
1210\end{array}$ & $\begin{array}{l}23256 \\
24896\end{array}$ & $\begin{array}{l}1648 \\
1236 \\
\end{array}$ & $\begin{array}{l}1.41 \\
1.51\end{array}$ & $\begin{array}{l}15.98 \\
15.45\end{array}$ & $\begin{array}{l}23.08 \\
33.17\end{array}$ & $\begin{array}{l}1.52 \\
1.40\end{array}$ \\
\hline 7 & $\begin{array}{l}0-20 \\
20-40\end{array}$ & $\begin{array}{l}0.10 \\
0.12\end{array}$ & $\begin{array}{l}7.39 \\
15.90\end{array}$ & $\begin{array}{l}1795 \\
2136\end{array}$ & $\begin{array}{l}24923 \\
21971\end{array}$ & $\begin{array}{l}1288 \\
2112\end{array}$ & $\begin{array}{l}1.36 \\
1.28\end{array}$ & & $\begin{array}{l}29.97 \\
14.77\end{array}$ & $\begin{array}{l}0.53 \\
0.41\end{array}$ \\
\hline 8 & $\begin{array}{l}0-20 \\
20-40\end{array}$ & $\begin{array}{l}0.09 \\
0.12\end{array}$ & $\begin{array}{l}4.48 \\
8.95\end{array}$ & $\begin{array}{l}2110 \\
1830\end{array}$ & $\begin{array}{l}28515 \\
28229\end{array}$ & $\begin{array}{l}1246 \\
1211\end{array}$ & $\begin{array}{l}1.81 \\
1.56\end{array}$ & $\begin{array}{l}13.05 \\
8.45\end{array}$ & $\begin{array}{l}32.56 \\
21.62\end{array}$ & $\begin{array}{l}0.33 \\
0.27\end{array}$ \\
\hline 9 & $\begin{array}{l}0-20 \\
20-40\end{array}$ & $\begin{array}{l}0.06 \\
0.06\end{array}$ & $\begin{array}{l}4.39 \\
3.23\end{array}$ & $\begin{array}{l}1634 \\
1679\end{array}$ & $\begin{array}{l}28371 \\
27813\end{array}$ & $\begin{array}{l}1217 \\
1213\end{array}$ & $\begin{array}{l}1.61 \\
1.74\end{array}$ & $\begin{array}{l}9.02 \\
10.50\end{array}$ & $\begin{array}{l}10.06 \\
13.29\end{array}$ & $\begin{array}{l}0.21 \\
0.23\end{array}$ \\
\hline 10 & $\begin{array}{l}0-20 \\
20-40 \\
\end{array}$ & $\begin{array}{l}0.08 \\
0.08\end{array}$ & $\begin{array}{l}7.98 \\
5.95\end{array}$ & $\begin{array}{l}1822 \\
1628 \\
\end{array}$ & $\begin{array}{l}20380 \\
19259\end{array}$ & $\begin{array}{l}4931 \\
5048\end{array}$ & $\begin{array}{l}2.03 \\
1.98 \\
\end{array}$ & $\begin{array}{l}26.83 \\
22.04\end{array}$ & $\begin{array}{l}24.78 \\
28.05\end{array}$ & $\begin{array}{l}0.61 \\
0.60\end{array}$ \\
\hline 11 & $\begin{array}{l}0-20 \\
20-40\end{array}$ & $\begin{array}{l}0.06 \\
0.07\end{array}$ & $\begin{array}{l}6.59 \\
4.33\end{array}$ & $\begin{array}{l}1935 \\
1830\end{array}$ & $\begin{array}{l}22132 \\
22099\end{array}$ & $\begin{array}{l}3266 \\
3241\end{array}$ & $\begin{array}{l}1.56 \\
1.60\end{array}$ & $\begin{array}{l}23.50 \\
19.17\end{array}$ & $\begin{array}{l}24.48 \\
25.25\end{array}$ & $\begin{array}{l}0.61 \\
0.64\end{array}$ \\
\hline 12 & $\begin{array}{l}0-20 \\
20-40\end{array}$ & $\begin{array}{l}0.10 \\
0.12\end{array}$ & $\begin{array}{l}8.28 \\
13.59\end{array}$ & $\begin{array}{l}1332 \\
1404\end{array}$ & $\begin{array}{l}20525 \\
20071\end{array}$ & $\begin{array}{l}5009 \\
5168\end{array}$ & $\begin{array}{l}2.19 \\
2.39\end{array}$ & $\begin{array}{l}26.17 \\
31.56\end{array}$ & $\begin{array}{l}21.38 \\
27.71\end{array}$ & $\begin{array}{l}0.69 \\
0.90\end{array}$ \\
\hline 13 & $\begin{array}{l}0-20 \\
20-40\end{array}$ & $\begin{array}{l}0.06 \\
0.07\end{array}$ & $\begin{array}{l}8.02 \\
5.97\end{array}$ & $\begin{array}{l}2046 \\
1977\end{array}$ & $\begin{array}{l}19634 \\
19259\end{array}$ & $\begin{array}{l}5171 \\
5076\end{array}$ & $\begin{array}{l}1.77 \\
1.49\end{array}$ & $\begin{array}{l}21.26 \\
17.20\end{array}$ & $\begin{array}{l}37.00 \\
30.94\end{array}$ & $\begin{array}{l}1.41 \\
0.84\end{array}$ \\
\hline 14 & $\begin{array}{l}0-20 \\
20-40\end{array}$ & $\begin{array}{l}0.07 \\
0.08\end{array}$ & $\begin{array}{l}6.86 \\
5.15\end{array}$ & $\begin{array}{l}1996 \\
1919\end{array}$ & $\begin{array}{l}18480 \\
18598\end{array}$ & $\begin{array}{l}5055 \\
5080\end{array}$ & $\begin{array}{l}1.72 \\
1.84\end{array}$ & $\begin{array}{l}31.26 \\
28.90\end{array}$ & $\begin{array}{l}32.50 \\
32.38\end{array}$ & $\begin{array}{l}1.48 \\
0.47\end{array}$ \\
\hline 15 & $\begin{array}{c}0-20 \\
20-40\end{array}$ & $\begin{array}{l}0.09 \\
0.09\end{array}$ & $\begin{array}{l}7.71 \\
3.02\end{array}$ & $\begin{array}{l}2004 \\
1838\end{array}$ & $\begin{array}{l}20222 \\
20257\end{array}$ & $\begin{array}{l}435 \\
4641\end{array}$ & $\begin{array}{l}1.82 \\
1.72\end{array}$ & $\begin{array}{l}21.53 \\
15.59\end{array}$ & $\begin{array}{l}29.32 \\
20.61\end{array}$ & $\begin{array}{l}0.51 \\
0.86\end{array}$ \\
\hline 16 & $\begin{array}{c}0-20 \\
20-40 \\
\end{array}$ & $\begin{array}{l}0.11 \\
0.11 \\
\end{array}$ & $\begin{array}{l}6.65 \\
10.75 \\
\end{array}$ & $\begin{array}{l}1934 \\
1838 \\
\end{array}$ & $\begin{array}{l}27501 \\
27838 \\
\end{array}$ & $\begin{array}{l}2011 \\
1719 \\
\end{array}$ & $\begin{array}{l}1.70 \\
1.65 \\
\end{array}$ & $\begin{array}{l}10.19 \\
8.56 \\
\end{array}$ & $\begin{array}{l}21.62 \\
16.55 \\
\end{array}$ & $\begin{array}{l}0.40 \\
0.34 \\
\end{array}$ \\
\hline 17 & $\begin{array}{c}20-20 \\
20-40\end{array}$ & $\begin{array}{l}0.11 \\
0.12\end{array}$ & $\begin{array}{l}2.96 \\
4.83\end{array}$ & $\begin{array}{l}1862 \\
1597\end{array}$ & $\begin{array}{l}24785 \\
23949\end{array}$ & $\begin{array}{l}1291 \\
1268\end{array}$ & $\begin{array}{l}1.87 \\
1.98\end{array}$ & $\begin{array}{l}12.26 \\
16.03\end{array}$ & $\begin{array}{l}25.16 \\
21.16\end{array}$ & $\begin{array}{l}0.42 \\
0.45\end{array}$ \\
\hline
\end{tabular}


Çizelge 3. (Devam)

\begin{tabular}{|c|c|c|c|c|c|c|c|c|c|c|}
\hline Toprak No & Derinlik & $\begin{array}{l}\mathrm{N} \\
\%\end{array}$ & $\begin{array}{l}\mathrm{P} \\
\mathrm{ppm}\end{array}$ & $\begin{array}{l}\mathrm{K} \\
\mathrm{ppm}\end{array}$ & $\begin{array}{l}\mathrm{Ca} \\
\mathrm{ppm}\end{array}$ & $\begin{array}{l}\mathrm{Mg} \\
\mathrm{ppm}\end{array}$ & $\begin{array}{l}\mathrm{Cu} \\
\mathrm{ppm}\end{array}$ & $\begin{array}{l}\mathrm{Fe} \\
\mathrm{ppm}\end{array}$ & $\begin{array}{l}\mathrm{Mn} \\
\mathrm{ppm}\end{array}$ & $\begin{array}{l}\mathrm{Zn} \\
\mathrm{ppm}\end{array}$ \\
\hline \multirow[t]{2}{*}{18} & $0-20$ & 0.08 & 2.60 & 1842 & 28328 & 2291 & 1.68 & 17.06 & 11.73 & 0.49 \\
\hline & $20-40$ & 0.08 & 1.75 & 2000 & 27924 & 2221 & 1.89 & 20.51 & 18.93 & 0.55 \\
\hline \multirow[t]{2}{*}{19} & $0-20$ & 0.09 & 3.80 & 2018 & 25408 & 2043 & 1.83 & 17.91 & 24.73 & 1.34 \\
\hline & $20-40$ & 0.12 & 2.43 & 1963 & 25592 & 1459 & 1.78 & 16.05 & 18.79 & 0.77 \\
\hline \multirow[t]{2}{*}{20} & $0-20$ & 0.16 & 20.92 & 1255 & 12228 & 4143 & 3.33 & 85.34 & 47.83 & 1.95 \\
\hline & $20-40$ & 0.14 & 23.14 & 1233 & 12113 & 4178 & 3.61 & 86.67 & 50.86 & 1.62 \\
\hline \multirow[t]{2}{*}{21} & $0-20$ & 0.08 & 4.75 & 1750 & 25952 & 1763 & 1.76 & 11.12 & 11.85 & 0.52 \\
\hline & $20-40$ & 0.08 & 4.31 & 1726 & 25463 & 2024 & 1.81 & 8.78 & 17.21 & 0.56 \\
\hline \multirow[t]{2}{*}{22} & $0-20$ & 0.15 & 11.88 & 2961 & 25287 & 1522 & 1.69 & 10.92 & 33.52 & 1.46 \\
\hline & $20-40$ & 0.14 & 6.42 & 2604 & 25328 & 1414 & 1.57 & 8.76 & 30.10 & 1.20 \\
\hline \multirow[t]{2}{*}{23} & $0-20$ & 0.10 & 15.16 & 2515 & 24868 & 2447 & 1.72 & 13.84 & 22.15 & 0.94 \\
\hline & $20-40$ & 0.10 & 10.28 & 2113 & 23723 & 2717 & 1.68 & 15.80 & 20.84 & 1.27 \\
\hline \multirow[t]{2}{*}{24} & $0-20$ & 0.13 & 16.57 & 1862 & 23971 & 2645 & 1.64 & 10.92 & 37.18 & 0.86 \\
\hline & $20-40$ & 0.14 & 9.96 & 1714 & 24569 & 1999 & 1.77 & 11.87 & 31.44 & 0.78 \\
\hline \multirow[t]{2}{*}{25} & $0-20$ & 0.15 & 10.09 & 1905 & 24390 & 734 & 1.78 & 7.25 & 15.78 & 0.53 \\
\hline & $20-40$ & 0.18 & 9.01 & 2092 & 23961 & 756 & 2.22 & 11.62 & 25.67 & 0.66 \\
\hline \multirow[t]{2}{*}{26} & $0-20$ & 0.08 & 7.45 & 1995 & 23971 & 936 & 2.10 & 8.66 & 15.58 & 0.48 \\
\hline & $20-40$ & 0.08 & 5.81 & 2000 & 23817 & 932 & 2.17 & 10.21 & 18.69 & 0.50 \\
\hline \multirow[t]{2}{*}{27} & $0-20$ & 0.21 & 9.27 & 2129 & 22074 & 1650 & 2.09 & 12.94 & 34.03 & 4.22 \\
\hline & $20-40$ & 0.25 & 13.74 & 2139 & 21673 & 1706 & 2.24 & 12.20 & 39.90 & 4.10 \\
\hline \multirow[t]{2}{*}{28} & $0-20$ & 0.13 & 8.11 & 2419 & 23503 & 1218 & 1.87 & 8.32 & 19.78 & 0.84 \\
\hline & $20-40$ & 0.12 & 7.49 & 2340 & 23251 & 1230 & 1.93 & 7.70 & 24.18 & 0.79 \\
\hline \multirow[t]{2}{*}{29} & $0-20$ & 0.22 & 26.98 & 3784 & 23208 & 2110 & 2.45 & 13.18 & 34.14 & 1.18 \\
\hline & $20-40$ & 0.15 & 17.42 & 3715 & 22984 & 2138 & 2.44 & 12.43 & 36.08 & 1.12 \\
\hline \multirow[t]{2}{*}{30} & $0-20$ & 0.17 & 5.76 & 1320 & 14753 & 6594 & 2.31 & 20.27 & 18.08 & 0.45 \\
\hline & $20-40$ & 0.05 & 2.55 & 949 & 14705 & 8103 & 2.49 & 21.64 & 15.26 & 0.31 \\
\hline \multirow[t]{2}{*}{31} & $0-20$ & 0.05 & 13.49 & 467 & 16241 & 4803 & 0.83 & 16.48 & 12.27 & 0.34 \\
\hline & $20-40$ & 0.05 & 10.94 & 517 & 15706 & 4786 & 0.89 & 17.11 & 16.17 & 0.39 \\
\hline \multirow[t]{2}{*}{32} & $0-20$ & 0.05 & 6.59 & 448 & 16144 & 3632 & 1.02 & 15.68 & 13.61 & 0.38 \\
\hline & $20-40$ & 0.04 & 8.23 & 409 & 16218 & 3485 & 0.99 & 13.67 & 14.15 & 0.32 \\
\hline \multirow[t]{2}{*}{33} & $0-20$ & 0.01 & 0.32 & 687 & 21709 & 3076 & 0.91 & 9.51 & 5.06 & 0.14 \\
\hline & $20-40$ & 0.01 & 0.63 & 431 & 21190 & 3595 & 0.65 & 5.71 & 3.16 & 0.09 \\
\hline \multirow[t]{2}{*}{34} & $0-20$ & 0.03 & 2.22 & 851 & 22486 & 783 & 0.68 & 4.63 & 5.15 & 0.10 \\
\hline & $20-40$ & 0.06 & 4.66 & 851 & 22352 & 772 & 0.71 & 4.83 & 6.21 & 0.11 \\
\hline \multirow[t]{2}{*}{35} & $0-20$ & 0.20 & 19.25 & 3235 & 18512 & 2041 & 1.52 & 3.65 & 5.68 & 1.12 \\
\hline & $20-40$ & 0.17 & 29.98 & 2961 & 18447 & 2071 & 1.83 & 9.65 & 13.06 & 1.58 \\
\hline \multirow[t]{2}{*}{36} & $0-20$ & 0.09 & 6.75 & 812 & 13689 & 3722 & 1.02 & 15.63 & 16.41 & 0.61 \\
\hline & $20-40$ & 0.02 & 3.69 & 694 & 13068 & 3396 & 0.91 & 11.73 & 16.05 & 0.47 \\
\hline \multirow[t]{2}{*}{37} & $0-20$ & 0.03 & 1.48 & 702 & 17458 & 2453 & 0.62 & 9.33 & 9.21 & 0.23 \\
\hline & $20-40$ & 0.01 & 4.16 & 390 & 14572 & 3021 & 0.54 & 7.19 & 7.53 & 0.19 \\
\hline 38 & $0-20$ & 0.04 & 1.77 & 709 & 17174 & 2448 & 0.55 & 9.17 & 9.01 & 0.22 \\
\hline & $20-40$ & 0.06 & 3.12 & 708 & 18380 & 1617 & 0.80 & 10.15 & 13.79 & 0.47 \\
\hline Min & & 0.01 & 0.32 & 390 & 12113 & 734 & 0.54 & 3.65 & 3.16 & 0.09 \\
\hline Max & & 0.25 & 29.98 & 3784 & 28515 & 8103 & 3.61 & 86.67 & 50.86 & 4.22 \\
\hline Ort.(Av.) & $0-20$ & 0.10 & 7.86 & 1746 & 21863 & 2786 & 1.68 & 16.84 & 21.42 & 0.84 \\
\hline Ort.(Av.) & $20-40$ & 0.10 & 7.69 & 1651 & 21592 & 2806 & 1.72 & 16.25 & 21.38 & 0.76 \\
\hline & Ort.(Av.) & 0.10 & 7.78 & 1698 & 21727 & 2796 & 1.70 & 16.55 & 21.40 & 0.80 \\
\hline
\end{tabular}

Toprak örneklerinin Viets ve Lindsay (1973)'in ortaya koyduğu sınır değerlere göre net bir şekilde demir noksanlığ $\quad(<2.5 \quad$ ppm $)$ gösteren topraklar belirlenememiştir. Kritik demir noksanlığı gösterme olasılığı bulunan (2.5-4.5 ppm) topraklar örneklerin \% 1.32 iken \% 98.68'i ise alınabilir demir açısından iyi (>4.5 ppm) durumdadır (Çizelge 3). Aynı bölgede Söylemez ve ark. (2017)'nın Şanlıurfa yöresi zeytinliklerinin beslenme durumunun belirlenmesi amacıyla yaptıkları çalışmada toprakları alınabilir demir içerikleri açısından herhangi bir problemin olmadığı belirtilmiştir.

\section{Mangan}

Çalışma alanının topraklarının alınabilir mangan içeriği en düşük 3.16 ppm iken en yüksek 50.86 ppm 
olarak belirlenmiştir. Toprakların 0-20 cm derinliğindeki örneklerinin ortalama mangan içeriği $21.42 \mathrm{ppm}$ iken $20-40 \mathrm{~cm}$ derinlikteki örneklerde 21.38 ppm olup her iki derinliğin ortalaması $21.40 \mathrm{ppm}$ olarak bulunmuştur. Şanlıurfa ili Siverek ilçesi yaygın toprak gurupları topraklarının hepsinin alınabilir mangan içerikleri Viets ve Lindsay (1973)'e göre yeterli düzeyde (>1 ppm) olduğu görülmüştür (Çizelge 3). Çetin ve Eraslan (2015) Afyonkarahisar ilinin Dinar ilçesinin verimlilik durumunu belirlemeyi amaçladıkları, Uyanöz ve ark. (2012) Konya iline bağlı Taşkent ve Hadım ilçelerindeki kiraz bahçelerinin beslenme durumları ile toprakların fiziksel ve kimyasal özelliklerini belirledikleri, Karaduman ve Çimrin (2016) Gaziantep yöresi yaygın toprak gruplarının verimlilik durumlarını belirledikleri, farklı bölgelerde yapılan çalışmalarda benzer olarak toprakların alınabilir mangan açısından yeterli olduğunu ortaya koymuşlardır.

\section{Çinko}

Siverek ilçesi toprak gurupları topraklarının alınabilir çinko içerikleri en düşük 0.09 ppm iken en yüksek 4.22 ppm olarak belirlenmiştir. Toprakların 0-20 cm derinliğindeki ortalama çinko içeriği 0.84 ppm iken 20$40 \mathrm{~cm}$ derinlikteki örneklerde ortalama ise $0.76 \mathrm{ppm}$ olup ortalama olarak $0.80 \mathrm{ppm}$ bulunmuştur. Siverek ilçesi yaygın toprak gurupları toprakları alınabilir çinko içerikleri Sillanpää (1990)'da belirlenen sınır değerlerine göre sınıflandırıldığında \% 6.58'i aşırı noksanlık $(<0.2 \mathrm{ppm}), \%$ 56.58'inde noksanlık (0.2-0.7 ppm). \% 34.21'inde kritik (0.7-2.4 ppm). \% 2.63'ünde ise yeterli (2.4-8.0 ppm) düzeyde olduğu belirlenmiştir (Çizelge 3). Şanlıurfanın farklı ilçesi olan Halfeti (Saraçoğlu ve ark., 2014) ve çalışma alanına komşu il olan Gaziantep yöresinde (Karaduman ve Çimrin, 2016) yapılan çalışmalarda paralel sonuçlar bildirilmiştir.

Toprakların bazı özellikleri ile alınabilir besin maddeleri arasındaki ilişkiler

Araştırma konusu toprak özelliklerinin bazı fiziksel ve kimyasal özellikleri ile makro ve mikro besin elementleri arasındaki ilişkiler Çizelge 4'de verilmiştir. Tablonun incelenmesinden de anlaşılacağ gibi toplam azot ile kum içeriği arasında negatif önemli $(\mathrm{r}:-0.39 * * *)$ ilişki belirlenir iken, toplam azot ile tuz (r: $\left.0.35^{* * *}\right)$, kireç (r: $\left.0.26^{*}\right)$, organik madde $\left(\mathrm{r}: 0.62^{* * *}\right)$ ve silt ile (r: $\left.0.35^{* * *}\right)$ pozitif önemli ilişkiler belirlenmiştir. Çimrin ve Boysan (2006) Van yöresi tarım topraklarında, Turan ve ark. (2010) Bursa ili alüviyal büyük toprak grubu tarım topaklarında ve Karadavut ve ark., (2011) Konya ilinde fiğ tarımı yapılan bazı alanlarında yaptıkları çalışmalarda toplam azot ile kum içeriği arasında negatif önemli ilişki belirlenirken silt ve organik madde arasında ise benzer olarak pozitif ilişkiler bulmuşlardır. Ayrıca, Akça ve ark., (2015) Ankara ili Kalecik ilçesi topraklarıda, toplam azot ile tuz ve organik madde özellikleri arasında pozitif önemli ilişkiler belirlemişlerdir.

Çalışmada toprakların fosfor içerikleri ile kireç ( $\mathrm{r}$ : $\left.0.35^{* * *}\right)$, organik madde $\left(\mathrm{r}: 0.52^{* * *}\right)$ ve kil içerikleri ( $\mathrm{r}$ : $\left.0.26^{*}\right)$ aralarında pozitif önemli ilişkiler saptanmıştır (Çizelge 4). Farklı bölgelerde çalışan, Karadavut ve ark. (2011) ile Chimrin ve Boysan (2006) toprakların fosfor içerikleri ile organik madde içerikleri aralarında pozitif önemli ilişki bulmuşlardır.

Toprakların potasyum içerikleri ile kum içeriğ arasında negatif önemli ( $\left.\mathrm{r}:-0.60^{* * *}\right)$ ilişki belirlenir iken potasyum ile tuz $\left(\mathrm{r}: 0.67^{* * *}\right)$, silt $\left(\mathrm{r}: 0.45^{* * *}\right)$, organik madde $\left(\mathrm{r}: 0.62^{* * *}\right)$ ve $\mathrm{KDK}\left(\mathrm{r}: 0.37^{* * *}\right)$ aralarında pozitif önemli ilişkiler belirlenmiştir (Çizelge 4). Parlak ve ark., (2008) ile Karadavut ve ark., (2011) farklı bir bölgede yaptıkları çalışmada değişebilir potasyum ile kum içeriği arasında negatif önemli bir ilişki belirleyerek benzer sonuçlar bulmuşlardır. Çimrin ve Boysan (2006) yaptıkları çalışmada toprakların potasyum içerikleri ile kum içerikleri arasında negatif önemli ilişki belirlerken, silt, organik madde ve KDK içerikleri aralarında ise pozitif önemli ilişki belirleyerek benzer sonuçları bulmuşlardır.

Ayrıca toprakların kalsiyum ile kil ( $\mathrm{r}:-0.30 * * *)$ ve kum içeriği $\left(\mathrm{r}:-0.51^{* * *}\right)$ arasında negatif önemli ilişki ortaya konulur iken kalsiyum ile $\mathrm{pH}\left(\mathrm{r}: 0.65^{* * *}\right)$, tuz $\left(\mathrm{r}: 0.53^{* * *}\right)$, silt $\left(\mathrm{r}: 0.63^{* * *}\right)$ ve KDK ile ise $\left(\mathrm{r}: 0.45^{* * *}\right)$ pozitif önemli ilişkiler saptanmıştır (Çizelge 4).

Turan ve ark., (2010) ile Parlak ve ark., (2008) farklı bir bölgede yaptıkları çalışmada kalsiyum ile kum içerikleri arasında ise negatif önemli ilişki belirlemişlerdir.

Aynı zamanda toprakların magnezyum ile $\mathrm{pH}(\mathrm{r}$ : $\left.0.71^{* * *}\right)$ ve kireç içeriği ( $\left.\mathrm{r}:-0.39^{* * *}\right)$ arasında negatif önemli ilişki ortaya konulur iken magnezyum ile kil içeriği $(\mathrm{r}: 0.39 * * *)$ arasında ise pozitif önemli ilişkiler saptanmıştır (Çizelge 4). Turan ve ark. (2010) farklı bir bölgede yaptıkları çalışmada magnezyum ile kil içerikleri arasında ise pozitif önemli ilişki belirlemişlerdir. Toprakların alınabilir bakır ile kum içeriği arasında negatif önemli $\left(\mathrm{r}:-0.62^{* * *}\right)$ ilişki belirlenir iken toprakların alınabilir bakır ile tuz ( $\mathrm{r}$ : $\left.0.43^{* * *}\right)$, silt $\left(\mathrm{r}: 0.50^{* * *}\right)$, organik madde $\left(\mathrm{r}: 0.45^{* * *}\right)$ ve KDK ile ise $\left(\mathrm{r}: 0.27^{*}\right)$ pozitif önemli ilişkiler bulunmuştur (Çizelge 4).

Farklı bölgede yapılan çalışmalarda Parlak ve ark. (2008), Karaduman ve Çimrin (2016) ile Karadavut ve ark., (2011) çalıştıkları toprakların bakır ile kum içeriği arasında negatif önemli ilişki belirlemişlerdir. Ayrıca, Çimrin ve Boysan (2006) farklı bir bölgede yaptıkları çalışmada alınabilir bakır ile kum içeriği arasında negatif önemli ilişki belirlerken silt, organik madde ve KDK arsında ise pozitif önemli ilişki belirleyerek benzer sonuçlar bulmuşlardır. 
Çizelge 4. Şanlıurfa ili Siverek ilçesi yaygın toprak guruplarının besin elementleri ile bazı toprak özellikleri arasındaki korelasyon katsayıları (r)

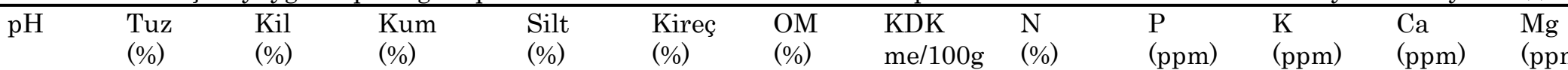

$\mathrm{Mg}$

$\begin{array}{ll}\mathrm{Cu} & \mathrm{Fe} \\ (\mathrm{ppm}) & (\mathrm{ppm})\end{array}$

\begin{tabular}{|c|c|c|c|c|c|c|c|c|c|c|c|c|c|c|c|}
\hline Tuz (\%) & 0.08 & & & & & & & & & & & & & & \\
\hline $\mathrm{Kil}(\%)$ & $-0.56^{\star \star *}$ & 0.04 & & & & & & & & & & & & & \\
\hline Kum (\%) & -0.07 & $-0.66^{\star * *}$ & -0.15 & & & & & & & & & & & & \\
\hline Silt (\%) & $0.37^{* \star *}$ & $0.59^{* * *}$ & $-0.40^{* * *}$ & $-0.85^{* * *}$ & & & & & & & & & & & \\
\hline Kireç (\%) & $0.43^{* * *}$ & -0.14 & -0.14 & 0.04 & 0.04 & & & & & & & & & & \\
\hline OM (\%) & 0.01 & $0.37^{* * *}$ & 0.10 & $-0.23^{* * *}$ & 0.22 & $0.32^{\star \star *}$ & & & & & & & & & \\
\hline $\begin{array}{l}\mathrm{KDK} \\
\mathrm{me} / 100 \mathrm{~g}\end{array}$ & -0.02 & $0.58^{* * *}$ & 0.13 & $-0.72^{\star \star \star}$ & $0.60^{* * *}$ & $-0.28^{*}$ & 0.02 & & & & & & & & \\
\hline N (\%) & 0.42 & $0.35^{* \star *}$ & 0.23 & $-0.39^{* * *}$ & $0.35^{* * *}$ & $0.26^{*}$ & $0.62^{\star * *}$ & 0.01 & & & & & & & \\
\hline $\mathrm{P}(\mathrm{ppm})$ & -0.10 & 0.19 & $0.26^{*}$ & -0.08 & -0.07 & $0.35^{* * *}$ & $0.52^{* * *}$ & -0.16 & $0.63^{* * *}$ & & & & & & \\
\hline $\mathrm{K}(\mathrm{ppm})$ & 0.20 & $0.67^{* \star *}$ & 0.19 & $-0.60^{* * *}$ & $0.45^{* * *}$ & 0.18 & $0.62^{\star \star \star}$ & $0.37^{\star \star \star *}$ & $0.64^{\star \star \star}$ & $0.49^{* \star \star}$ & & & & & \\
\hline $\mathrm{Ca}(\mathrm{ppm})$ & $0.65^{* \star \star}$ & $0.53^{* \star *}$ & $-0.30^{* * *}$ & $-0.51^{* * *}$ & $0.63^{* * *}$ & 0.20 & 0.19 & $0.45^{* * *}$ & 0.11 & -0.19 & $0.49^{* * *}$ & & & & \\
\hline $\mathrm{Mg}(\mathrm{ppm})$ & $-0.71^{\star * *}$ & -0.06 & $0.39^{\star \star *}$ & -0.01 & -0.21 & $-0.39^{* * *}$ & -0.11 & 0.20 & -0.19 & 0.02 & $-0.29^{\star \star *}$ & $-0.65^{* * *}$ & & & \\
\hline $\mathrm{Cu}(\mathrm{ppm})$ & -0.19 & $0.43^{* * *}$ & 0.15 & $-0.62^{\star * *}$ & $0.50^{* * *}$ & 0.08 & $0.45^{* * *}$ & $0.27^{*}$ & $0.62^{\star * *}$ & $0.40^{* * *}$ & $0.43^{* * *}$ & 0.15 & 0.22 & & \\
\hline $\mathrm{Fe}(\mathrm{ppm})$ & $-0.61^{* * *}$ & 0.03 & $0.37^{* * *}$ & -0.22 & 0.01 & -0.04 & 0.08 & 0.03 & 0.18 & $0.31^{* * *}$ & -0.11 & $-0.45^{* * *}$ & $0.48^{* * *}$ & $0.68^{* * *}$ & \\
\hline $\mathrm{Mn}(\mathrm{ppm})$ & $-0.43^{* * *}$ & $0.45^{* * *}$ & $0.42^{\star \star *}$ & $-0.53^{* * *}$ & $0.26^{*}$ & -0.02 & $0.36^{* * *}$ & 0.15 & $0.48^{* * *}$ & $0.43^{* \star *}$ & $0.42^{* * *}$ & -0.02 & 0.13 & $0.53^{* * *}$ & $0.51^{* * *}$ \\
\hline $\mathrm{Zn}(\mathrm{ppm})$ & -0.13 & 0.23 & 0.12 & $-0.29^{*}$ & 0.20 & -0.01 & $0.27^{*}$ & 0.01 & $0.67^{* * *}$ & $0.39^{* * *}$ & $0.34^{* * *}$ & -0.09 & 0.01 & $0.50^{* * *}$ & $0.33^{\star * *}$ \\
\hline
\end{tabular}


Toprakların alınabilir demir ile pH içeriği (r: $\left.-0.61^{* * *}\right)$ arasında negatif önemli ilişki belirlenir iken toprakların alınabilir demir ile kil (r: $\left.0.37^{* * *}\right)$ içeriği arasında ise pozitif önemli ilişkiler saptanmıştır (Çizelge 4). Turan ve ark. (2010) yaptıkları çalışmada alınabilir demir ile $\mathrm{pH}$ değerleri arasında ise negatif önemli ilişki belirleyerek benzer sonuçlar bulmuşlardır. Soba ve ark., (2015) ve Parlak ve ark., (2008) yaptıkları benzer çalışmalarda toprakların alınabilir demir ile kil içeriği özellikleri arasında pozitif önemli ilişki belirlemişlerdir.

Topraklarm alınabilir mangan ile $\mathrm{pH}\left(\mathrm{r}:-0.43^{* * *}\right)$, kum $\left(-0.53^{* * *}\right)$ içerikleri arasında negatif önemli ilişki belirlenir iken alınabilir mangan ile tuz ( $\left.\mathrm{r}: 0.45^{* * *}\right)$, kil $\left.\mathrm{r}: 0.42^{* * *}\right)$, silt $\left(\mathrm{r}: 0.26^{*}\right)$ ve organik madde $\left(\mathrm{r}: 0.36^{* * *}\right)$ arasında pozitif önemli ilişkiler belirlenmiştir. Turan ve ark., (2010) farklı bir bölgede yaptıkları çalışmada alınabilir mangan ile $\mathrm{pH}$ değerleri arasında negatif önemli ilişkiler belirleyerek benzer sonuçlar bulmuşlardır.Ayrıca toprakların alınabilir Zn ile kum içeriği $\left(\mathrm{r}\right.$ : $\left.-0.29^{*}\right)$ arasında negatif önemli ilişki belirlenir iken alınabilir $\mathrm{Zn}$ ile organik madde ( $\mathrm{r}$ : $0.27^{*}$ ) arasında ise pozitif önemli ilişki belirlenmiştir.

\section{SONUÇ}

Şanlıurfa ili Siverek ilçesi yaygın toprak guruplarının bazı makro ve mikro besin elementleri miktarları ve bunların bazı toprak özellikleri ile ilişkileri belirlenerek, toprakların verimlilik durumlarının belirlenmesi amaçlanmıştır.

Çalışma sonunda, Siverek ilçesi yaygın toprak gurupları topraklarının toprak reaksiyonu yönünden genelde bitki yetiştirmeye elverişli nötür ile hafif alkalin karekterde, topakların bütününün tuzsuz sinıfta yer alması, tuz bakımından herhangi bir problemin bulunmadığın göstermektedir. Topraklar 8 farklı bünye sınıfına sahip olduğu ve toprakların genelinde ise \% 72.41'inin killi tın, kil ve siltli killi tın içerikli, kireç yönünden kireçli ile orta kireçli ve az ile orta oranda organik madde içeriğine sahip olduğu görülmüştür.

Calışma alanı topraklarının verimlilik bakımından incelendiğinde toplam azot yönünden toprakların 0-20 $\mathrm{cm}$ derinliklerde \% 18.42'si çok düşük (<0.05 ppm) ile $\%$ 44.73'ü düşük (0.05-0.09 ppm) ve $20-40 \mathrm{~cm}$ derinliklerde ise \% 15.79'u çok düşük $(<0.05 \mathrm{ppm})$ ile \% 36.84'ü düşük (0.05-0.09 ppm) arasında olup bütün toprakların yarıdan fazlasında azot yönünden yetersiz olduğu belirlenmiştir.

Yarayışlı fosfor açısından bakıldığında toprakların 0$20 \mathrm{~cm}$ derinliklerde \% 13.16'si çok düşük (<2.5 ppm), \% 55.26 'i düşük (2.5-8 ppm), \% 28.95' i yeterli (8-25 ppm), $\% 2.63$ ' ü ise fazla $(25-80 \mathrm{ppm})$ olduğu ve $20-40 \mathrm{~cm}$ derinliklerde ise \% 5.26'sı çok düşük $(<2.5 \mathrm{ppm})$, \% 57.90 ' 1 düşük (2.5-8 ppm), \% 34.21' i yeterli (8-25 ppm) ve \% 2.63' ü fazla (25-80 ppm) arasında olup tüm toprakların yarısından fazlasında yarayışlı fosfor bakımından yetersiz olduğu bulunmuştur.

Toprakların alınabilir çinko bakımından 0-20 cm derinliklerinde \% 5.26'sı aşırı yetersiz $(<0.2 \mathrm{ppm})$ ile \% 57.89 'u yetersiz $(0.2-0.7 \mathrm{ppm})$ ve $20-40 \mathrm{~cm}$ derinlikte ise \% 7.89' aşırı yetersiz $(<0.2 \mathrm{ppm})$ ile \% 55.26'sı yetersiz (0.2-0.7 ppm) arasında olup alınabilir çinko yönünden toprakların yaklaşık üçte ikisine yakınında noksanlık görülmüştür.

Özetle çalışma alanı topraklarıda azot, fosfor ve çinko yönünden gübrelemeye ihtiyaçları olduğu, ancak değişebilir potasyum, kalsiyum, magnezyum, alınabilir bakır, demir ve mangan açısından her hangi bir noksanlığa rastlanmamıştır. Yeterlilik sınırının altında olan besin elementleri için sera ve tarlada kalibrasyon denemeleriyle topraktan ve yapraktan uygun gübre çeşidi ve dozu belirlenerek gübre önerilerinin ekonomik ve ekolojik uygulanması sağlanacaktır.

\section{KAYNAKLAR}

Akça MO, Türkmen F, Taşkın MB, Soba MR, Öztürk HS, 2015. Ankara Üniversitesi Kalecik Araştırma ve Uygulama Çiftliği topraklarının verimlilik durumlarının incelenmesi, Toprak Bilimi ve Bitki Besleme Dergisi 3 (2) 54-63.

Allison LE, Moode CD 1965. Carbonate. (ed: C.A. Black). Methods of Soil Analysis. Part 2. Agronomy Series. No. 9. ASA. 1379-1396. Wisconsin.

Ateş K, Turan V 2015. Bingöl İli Merkez İlçesi Tarım Topraklarını Bazı Özellikleri ve Verimlilik Düzeyi. Türkiye Tarımsal Araştırma Dergisi. 2 (2): 108-113.

Bouyoucos GJ 1952. A Recalibration of The Hydrometer for Making Mechanical Analysis of Soil. Agronomy Journal. 43 (9): 434-438.

Bremner JM 1965. Methods of Soils Analysis. Part 2. Chemical and Microbiological Properties. Ed. CA Black. Amer. Soc. Agr. Inc. Publisher Agro. Series No: 9. Madison. USA.

Chapman HD 1965. Cation Exchange Capasity. In: C.A. Black et al. (ed.). In: Methods of Soil Analysis. ASA. Inc. Agronomy. 9: 891-901. Wisconsin.

Çetin E, Eraslan F 2015. Afyonkarahisar ili dinar ilçesi patates ekim alanlarında toprakların verimliliği ve bitkilerin beslenme durumlarının belirlenmesi. Süleyman Demirel Üniversitesi Ziraat Fakültesi Dergisi. 10 (2): 123-145.

Çimrin KM, Boysan S 2006. Van Yöresi Tarım Topraklarını Besin Elementi Durumları ve Bunların Bazı Toprak Özellikleri İle İlişkileri. Yüzüncü Yıl Üniversitesi Ziraat Fakültesi Tarım Bilimleri Dergisi. (J. Agric. Sci.). 16(2): 105-111.

Demir G, Erdal I. 2016. Antalya yöresinde domates yetiştirilen seralarda bor düzeylerinin bazı toprak, yaprak ve meyve analiz sonuçlarıyla 
değerlendirilmesi. Toprak Bilimi ve Bitki Besleme Dergisi 4 (2) 42-48.

FAO 1990. Micronutrient. Assessment at the country leaves an international study. FAO

Gürel S, Başar H 2006. Yalova yöresinde örtü altında yetiştirilen hıyarın beslenme durumunun toprak ve bitki analizleri ile incelenmesi i.sera topraklarının verimlilik durumları. Uludağ Üniversitesi Ziraat Fakültesi Dergisi 21(2) :1-7.

IUSS Working Group WRB. 2015. World Reference Base for Soil Resources 2014, update 2015 International soil classification system for naming soils and creating legends for soil maps. World Soil Resources Reports No. 106. FAO, Rome.

Jackson ML 1960. Soil Chemical Analysis. PrenticeHall. Inc. Englewood. Cliffs. NJ.

Karadavut U, Palta Ç, Bitgi S, Okur O, Çarkacı DA. 2011. Konya ilinde fig tarımı yapılan bazı alanlarında makro ve mikro besin elementi içeriklerinin belirlenmesi. Iğdır Üniversitesi Fen Bilimleri Enstitüsü Dergisi 1(3): 105-109.

Karaduman A, Çimrin KM 2016. Gaziantep Yöresi Topraklarının Besin Elementi Durumları ve Bunların Bazı Toprak Özellikleri İle İlişkileri. KSÜ Doğa Bilimleri Dergisi. 19(2). 117-129.

Kızılgöz İ, Kızılkaya R, Açar İ, Seyrek A, Kaptan H 1999. Şanlıurfa yöresinde antepfistığ (Pistacia vera L.) yetiştirilen toprakların verimlilik düzeylerinin saptanması üzerine bir araştırma. GAP I. Tarım Kongresi, 26-28 Mayıs 1999. II. Cilt:987-994. Şanlıurfa.

Knudsen D, Peterson GA, Pratt PF 1982. Lithium. Sodium. and Potassium. In: A.L. Page (editor). Methods of Soil Analysis. Part 2. Chemical and Microbiological Properties. Second edition. ASA. Inc.. 9: 225-246. Wisconsin.

Kovancı İ 1969. İzmir Bölgesi Tarla Topraklarında Nitrifikasyon Durumu ve Bunların Bazı Toprak Özelliği ile Olan İlişkisi Üzerinde Araştırmalar. Ege Üniversitesi Ziraat Fakültesi Bitki Besleme Kürsüsü (basılmamış doçentlik tezi). İzmir.

Lindsay WL, Norwel WA 1978. Development of a DTPA test for zinc. iron. manganese and copper. J. Soil Sci. Am.. 42. 421-428.

Olsen SR, Cole CV, Watanable FS, Dean LA 1954. Estimation of Available Phosphorus in Soils by Extraction With Sodium Bicarbonate. U. S. Dept. of Agric. Cir. 939. Washington D. C.

Parlak M, Fidan A, Kızılcık İ, Koparan H 2008. Eceabat İlçesi (Çanakkale) Tarım Topraklarının Verimlilik Durumlarının Belirlenmesi. Tarım Bilimleri Dergisi. 14(4): 394-400.

Richards LA 1954. Diagnosis and Improvement of Saline and Alkali Soils. USDA Handbook. 60 p.

Saraçoğlu M, Anlağan Taş M, Koşar İ, Aydoğdu M, Kara H, Sürücü A, Oğur Özkan N 2013. Şanlıurfa İli Hilvan ilçesi kuru alanlardaki toprakların bitki besin elementi kapsamlarının belirlenmesi.
6.Ulusal Bitki Besleme ve Gübreleme Kongresi. 3-7 Haziran 2013. Toprak Gübre ve Su Kaynakları Merkez Araştırma Enstitüsü Müdürlüğü-Nevşehir.

Saraçoğlu M, Polat H, Anlağan Taş M, Koşar I, Yetim S, Sürücü A 2010. Şanlıurfa İli Harran ilçesi kuru alanlardaki toprakların bitki besin elementi kapsamlarmn belirlenmesi. I.Ulusal Toprak ve $\mathrm{Su}$ Kongresi. 1-4 Haziran 2010. Toprak ve Su Kaynakları Araştırma Enstitüsü MüdürlüğüEskişehir.

Saraçoğlu M, Sürücü A, Koşar İ, Taş MA, Aydoğdu M, Kara H 2014. Şanlıurfa İli Halfeti İlçesi Topraklarının Bazı Özellikleri ve Bitki Besin Elementi Kapsamlarının Belirlenmesi. Toprak Bilimi ve Bitki Besleme Dergisi. 2 (2): 38-45.

Saraçoğlu M, Taş M, Koşar İ, Yetim S, Sürücü A 2009. Şanlıurfa İli Bozova ilçesi topraklarının bitki besin elementi kapsamlarının belirlenmesi. IX. Ulusal Ekoloji ve Çevre Kongresi. 7-10 Ekim 2009. Nevşehir.

Seyrek A, Kızılgöz İ, Çullu MA, İnce F 1999. Harran ovasında taban suyu etkisindeki toprakların ağır metal içerikleri. GAP 1. Tarım Kongresi, 26-28 Mayıs 1999, Şanlıurfa.

Sillanpää M 1990. Micronutrient assessment at the country level: An international study. In : FAO Soils Bulletin. N. 63.

Soba M, Türkmen F, Taşkın MB, Akça MO, Öztürk HS 2015. Ankara üniversitesi ziraat fakültesi haymana araştırma ve uygulama çiftliği topraklarının verimlilik durumlarını incelenmesi. Toprak $\mathrm{Su}$ Dergisi, 2015, 4 (1): 7-17.

Sönmez S, Orman Ş, Çıtak S, Kocabaş Oğuz I, Kalkan H, Uras DS, Ok H, Özsayın Çıtak S, Yılmaz E, Sönmez NK, Kaplan M. 2014. Kumluca ve Finike yöreleri turunçgil bahçelerinin beslenme durumlarının belirlenmesi. Akdeniz Üniversitesi Ziraat Fakültesi Dergisi 27(1): 51-59.

Söylemez S, Öktem AG, Kara H, Almaca ND, Ak BE, Sakar E 2017. Şanlıurfa yöresi zeytinliklerinin beslenme durumunun belirlenmesi. Harran Tarım ve Gida Bilimleri Dergisi 21(1): 1-15.

SPSS. IBM Corp. Released 2012. IBM SPSS Statistics for Windows, Versiyon 21.0. Armonk, NY, USA: IBM Corp.

Sumner ME, Miller, WP 1996. Cation exchange capacity and exchange cations. pp. 1201-1229. In: Sparks, D.L. (Ed), methods of Soil Analysis. Part 3, Chemical Methods, ASA and SSSA, Madison, WI, SSSA Book Series No: 5.

Turan MA, Katkat AV, Özsoy G, Taban S 2010. Bursa İli Alüviyal Tarım Topraklarının Verimlilik Durumları ve Potansiyel Beslenme Sorunlarının Belirlenmesi. Uludağ Üniversitesi Ziraat Fakültesi Dergisi. 24(1): 115-130.

Uyangöz R, Karaca Ü, Zengin M. 2012. Konya ili Taşkent ve Hadim ilçeleri kira bahçelerinin 
beslenme durumları. Selçuk Üniversitesi Selçuk Tarım ve Gıda Biliimleri Dergisi, 26(2): 40-45.

Viets FG, Lindsay WL 1973. Testing Soils for Zinc.. Copper. Managanese and Iron. Soil Soc. Of Amer. Inc.. Madison Wisconcin. USA. 153-172.
Yalçın M, Çimrin KM 2017. Hatay ili KırıkhanReyhanlı bölgesi çayır - mera topraklarının bor içeriğinin belirlenmesi ve toprağın bazı özelikleri ile ilişkilerinin belirlenmesi. Mesleki Bilimler Dergisi, 6(2): 201-210. 